\title{
Scorpions collected in the island of Espiritu Santo (Vanuatu) and description of a new species of Lychas C. L. Koch, 1845 (Arachnida, Scorpiones, Buthidae)
}

\author{
Wilson R. LOURENÇO \\ Muséum national d'Histoire naturelle, Département Systématique et Évolution, \\ USM 0602, Section Arthropodes (Arachnologie), \\ case postale 53, 57 rue Cuvier, F-75231 Paris cedex 05 (France) \\ arachne@mnhn.fr
}

\section{KEY WORDS \\ Arachnida, \\ Scorpiones, \\ Buthidae, \\ Lychas, \\ Vanuatu, \\ Espiritu Santo, new species.}

MOTS CLÉS

Arachnida,

Scorpiones,

Buthidae, Lychas,

Vanuatu,

Espiritu Santo, espece nouvelle.
Lourenço W. R. 2009. - Scorpions collected in the island of Espiritu Santo (Vanuatu) and description of a new species of Lychas C. L. Koch, 1845 (Arachnida, Scorpiones, Buthidae). Zoosystema 31 (3): 731-740.

\section{ABSTRACT}

Two species of scorpions were collected during the SANTO 2006 Expedition: Liocheles australasiae (Fabricius, 1775), family Liochelidae Fet \& Bechly, 2001 and, Lychas santoensis n. sp., family Buthidae C. L. Koch, 1837. The new species is characterized by: moderate to small size for the genus (from 29 to $31 \mathrm{~mm}$ in total length); general colouration reddish-yellow to reddish-brown with intense blackish variegated pigmentation throughout body and appendages; pectines with 10 to 12 teeth; fulcra absent or inconspicuous; telson moderately elongated; aculeus moderately curved; subaculear tooth moderate and, between rhomboid and spinoid in shape; granules on the ventral surface inconspicuous; tibial spurs present on legs III and IV; pedipalp fixed and movable fingers with 6-7 (6) rows of granules, and with one very inconspicuous external accessory granule next to the most basal row of granules.

\section{RÉSUMÉ}

Scorpions récoltés sur l'île d'Espiritu Santo (Vanuatu) et description d'une nouvelle espèce de Lychas C. L. Koch, 1845 (Arachnida, Scorpiones, Buthidae).

Deux espèces de scorpions ont été collectées dans l'île d'Espiritu Santo: Liocheles australasiae (Fabricius, 1775), famille des Liochelidae Fet \& Bechly, 2001 et Lychas santoensis n. sp., famille des Buthidae C. L. Koch, 1837. La nouvelle espèce est caractérisée par: taille totale petite à moyenne pour le genre (longueur totale de 29 à $31 \mathrm{~mm}$ ); coloration générale jaune-rougeâtre à rouge-brunâtre avec une intense trame de pigments noirâtres sur toute la surface du corps et des appendices; peignes avec 10 à 12 dents; fulcra absents ou à peine marqués; telson peu allongé; aiguillon faiblement courbé; tubercule sous-aiguillonaire de taille modeste et entre rhomboïdal et spinoide; granules sur la face ventral peu marqués; éperons tibiaux présents sur les pattes III et IV; tranchant des doigts fixe et mobile des pédipalpes avec 6-7 (6) séries de granules, et avec un granule accessoire externe très peu marqué près de la série de granules la plus basale. 


\section{INTRODUCTION}

Scorpions collected in Vanuatu remain rare in collections, and very few cases have been precisely documented in the literature. One precise example is given by Monod (2000) and concerns exclusively the species Liocheles australasiae (Fabricius, 1775) which belongs to the family Liochelidae Fet $\&$ Bechly, 2001.

The SANTO 2006 Expedition allowed the collection of several scorpion specimens. A large majority of the specimens were, once again, identified as belonging to the species $L$. australasiae. Two specimens, however, proved to be a new species of the genus Lychas C. L. Koch, 1845. The new species is described below. It also corresponds to the first record of the genus Lychas in Vanuatu Islands. Species of this genus have been previously described or reported from New Guinea, Solomon Islands and Fiji Islands (Koch 1977; Francke \& Lourenço 1991; Lourenço \& Qi 2007).

\section{MATERIAL AND METHODS}

Illustrations and measurements were produced using a Wild M5 stereo-microscope with a drawing tube (camera lucida) and an ocular micrometer. Measurements follow Stahnke (1970) and are given in $\mathrm{mm}$. Trichobothrial notations follow Vachon (1974) and morphological terminology mostly follows Vachon (1952) and Hjelle (1990).

For a narrative of the SANTO 2006 expedition, see Bouchet et al. (2008), and for a review of the geography and natural history of Santo, we refer to Bouchet et al. (in press).

Material is deposited in the MNHN.

\section{ABBREVIATIONS}

BMNH Natural History Museum, London;

MCSN Museo Civico di Storia Naturale "G. Doria”, Genova;

MNHN Muséum national d'Histoire naturelle, Paris.

\section{SYSTEMATICS}

Family Liochelidae Fet \& Bechly, 2001 Genus Liocheles Sundevall, 1833

\section{Liocheles australasiae (Fabricius, 1775)}

(Fig. 1)

Material eXAmined. - Vanuatu. Espiritu Santo Island, Camp Perouse, L. Albenga, 11.XI.2006, 1 ○ (dry specimen). - Bill's cave, under stone, $151.7514^{\circ} \mathrm{S}$, 166.95854 ${ }^{\circ} \mathrm{E}, 25 . \mathrm{XI} .2006$, C. Rollard, 1 \%. - Latautei, in forest, $512 \mathrm{~m}, 151.9596^{\circ} \mathrm{S}, 166.68676^{\circ} \mathrm{E}, 11 . \mathrm{XI} .2006$, C. Rollard, 1 juvenile. - Mangrove Palikoulo, $154.9780^{\circ} \mathrm{S}$, 167.25135ㄹ, 28.XI.2006, C. Rollard, 3 juveniles. Matantas Reserve, in forest, $151.6906^{\circ} \mathrm{S}, 166.94731^{\circ} \mathrm{E}$, 24.XI.2006, C. Rollard, 2 \% . - Pénaoru, Soustéo, in forest, $149.6448^{\circ} \mathrm{S}, 166.63662^{\circ} \mathrm{E}, 14 . X I .2006$, C. Rollard, 6 ㅇ, 1 juvenile, brood with 5 juveniles. - West road, $155.5676^{\circ} \mathrm{S}, 166.96789^{\circ} \mathrm{E}, 10 \mathrm{~m}, 30 . \mathrm{XI} .2006$, C. Rollard, 2 ㅇ. - - Tasmate Village, Mamasa River, $152.1629^{\circ} \mathrm{S}, 166.66442^{\circ} \mathrm{E}$, under stone, 8.XI.2006, C. Rollard, 1 female. - Idem, 10.XI.2006, local children, 10 ㅇ. - Wonakum, near River Pélapa, in forest, $60 \mathrm{~m}$, $151.7161^{\circ} \mathrm{S}, 166.66528^{\circ} \mathrm{E}, 10 . X I .2006$, C. Rollard, 5 ㅇ․ - - Wurahawo, in forest soil, $66 \mathrm{~m}, 152.1124^{\circ} \mathrm{S}$, 166.67564 ${ }^{\circ}$, 9.XI.2006, C. Rollard, 2 juveniles. Wurahawo, in forest, under stones, $112 \mathrm{~m}, 152.1087^{\circ} \mathrm{S}$, 166.67939 ${ }^{\circ}$ E, 9.XI.2006, C. Rollard, 2 ㅇ, 1 juvenile. In forest, $400 \mathrm{~m}, 151.95839^{\circ} \mathrm{S}, 166.68536^{\circ} \mathrm{E}, 11 . \mathrm{XI} .2006$, C. Rollard, 3 우 우, 1 juvenile.

\section{REMARK}

Considering that a total of 31 females were collected but no males, most certainly this population is also parthenogenetic. This phenomenon has already been observed for other populations of Liocheles australasiae, in distinct islands of the Pacific zone. For details see Lourenço (2008).

\section{Family Buthidae C. L. Koch, 1837 Genus Lychas C. L. Koch, 1845}

\section{Lychas santoensis n. sp.}

(Figs 2-5)

Material Examined. - Vanuatu. Espiritu Santo Island, Pénaoru, Camp I, $149.6931^{\circ} \mathrm{S}, 166.65665^{\circ} \mathrm{E}, 900 \mathrm{~m}$, low dense humid forest, 16.XI.2006, C. Rollard, o holotype. - Pénaoru, $149.6700^{\circ} \mathrm{S}, 166.6622^{\circ} \mathrm{E}, 1100 \mathrm{~m}$, transition forest, 17.XI.2006, C. Rollard, o paratype.

COMPARATIVE MATERIAL EXAMINED. - Lychas perfidus (original name Isometrus perfidus Keyserling, 1885) (= Archisometrus perfidus): Fiji. Viti Levu - e Mus. Godeffroy. Kpt. Pöhl det., 20.II.1894, 3 paralectotypes, 1 \% (lectotype), 2 o' ơ juveniles (BMNH). 


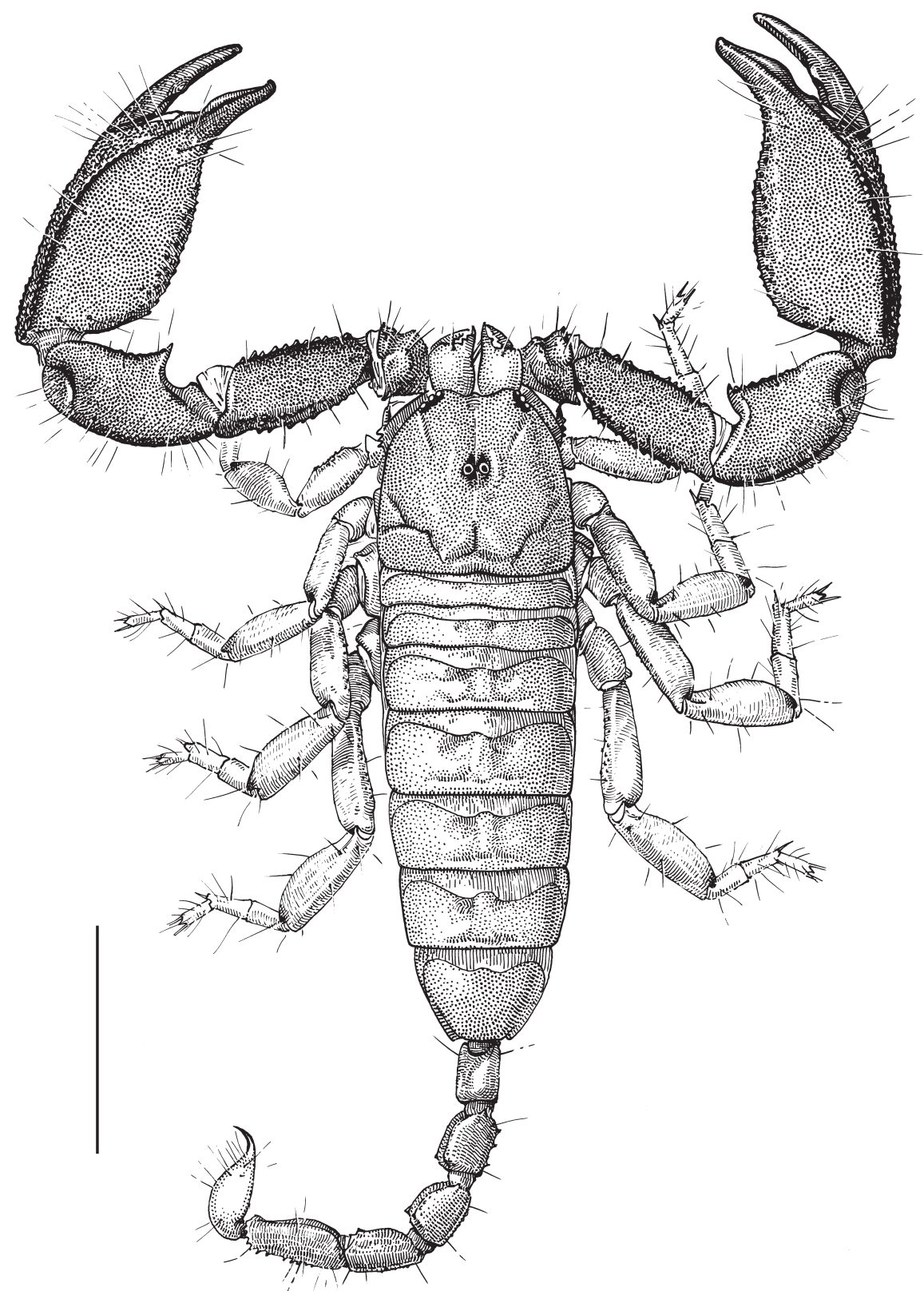

Fig. 1. - Habitus of Liocheles australasiae (Fabricius, 1775), ơ (from Lourenço 1985). Scale bar: $1 \mathrm{~cm}$.

Isometrus variatus papuanus Thorell, 1888: New Guinea. Yule, C. York (Somerset) leg. L. M. D’Albertis, 2 우, lectotype and paralectotype (MCSN).

DiAGNOSIS. - Scorpions of moderate to small size, with respect to the genus, measuring $31 \mathrm{~mm}$ for females. General colouration reddish-yellow to reddish-brown with very intense blackish variegated pigmentation over the body and appendages. Carinae and granulations moderate to strong. Pectines small; pectinal tooth count 12 or 11 for female holotype and 10 or 11 for female paratype; fulcra absent or inconspicuous. Dentate margins of fixed and movable 


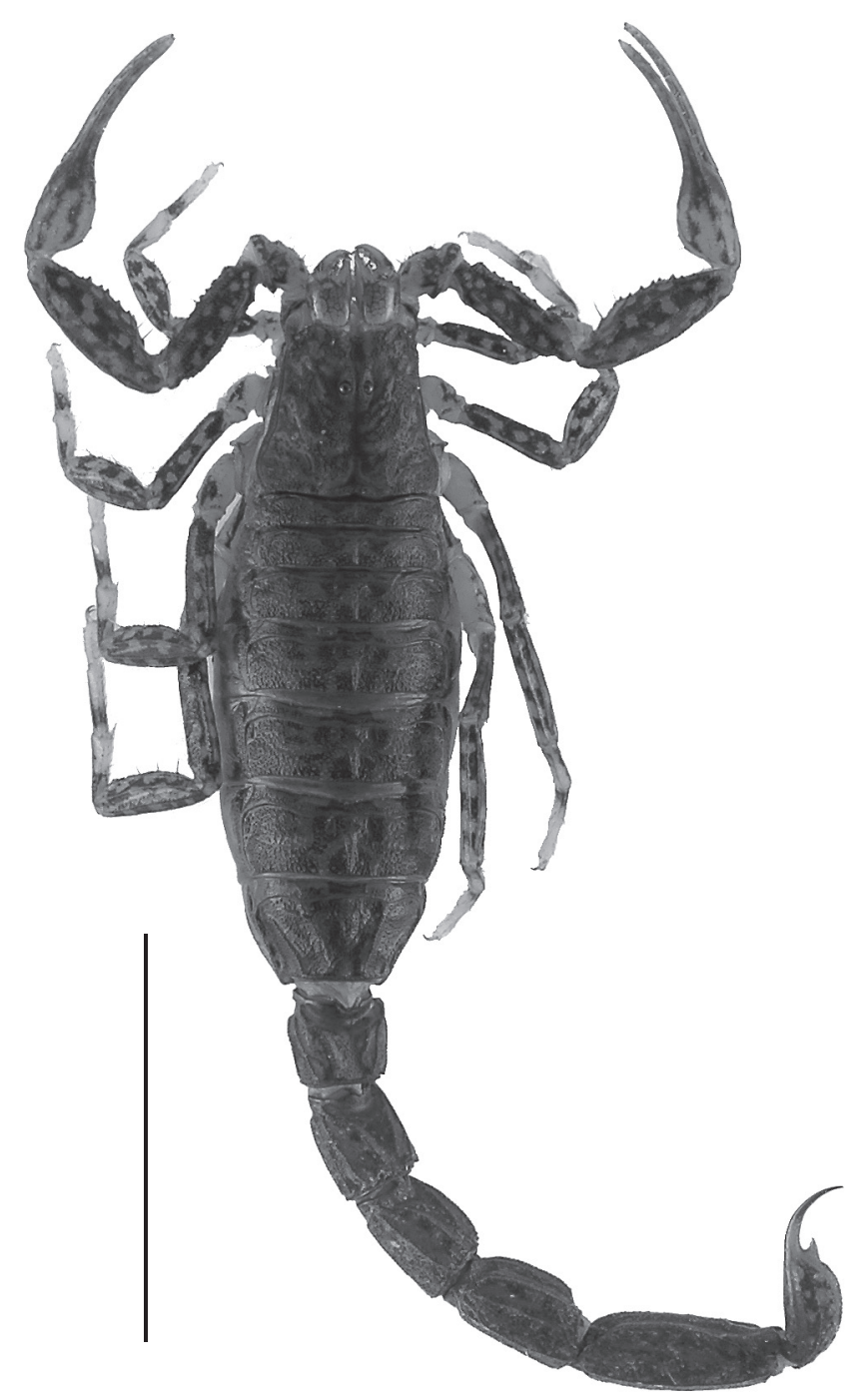

FIG. 2. - Lychas santoensis n. sp., \% holotype, habitus, dorsal aspect. Scale bar: $1 \mathrm{~cm}$.

fingers of pedipalp chela with 6 or 7 (6-see remarks) almost linear rows of granules; one very inconspicuous external accessory granule next to the most basal row of granules. Subaculear tubercle moderate, between rhomboid and spinoid in shape; ventral granules inconspicuous.

ETymology. - The specific name refers to the Island of Espiritu Santo (Vanuatu) where the new species was collected.

\section{RELATIONSHIPS}

From its general morphology, Lychas santoensis n. sp. is certainly related to Lychas variatus papuanus (Thorell,
1888), described from Yule Island in New Guinea, but also to Lychas perfidus (Keyserling, 1885), described from Viti Levu Island, Fiji. In fact, the new species appears to occupy an intermediate morphological position between the two other species, what is also consistent with their respective geographical areas of distribution. Lychas santoensis n. sp. can, however, be distinguished from the other two species by the following characters: 1 ) darker overall colouration and a much more intense blackish variegated pigmentation on body and appendages; 2) distinct shape of the 


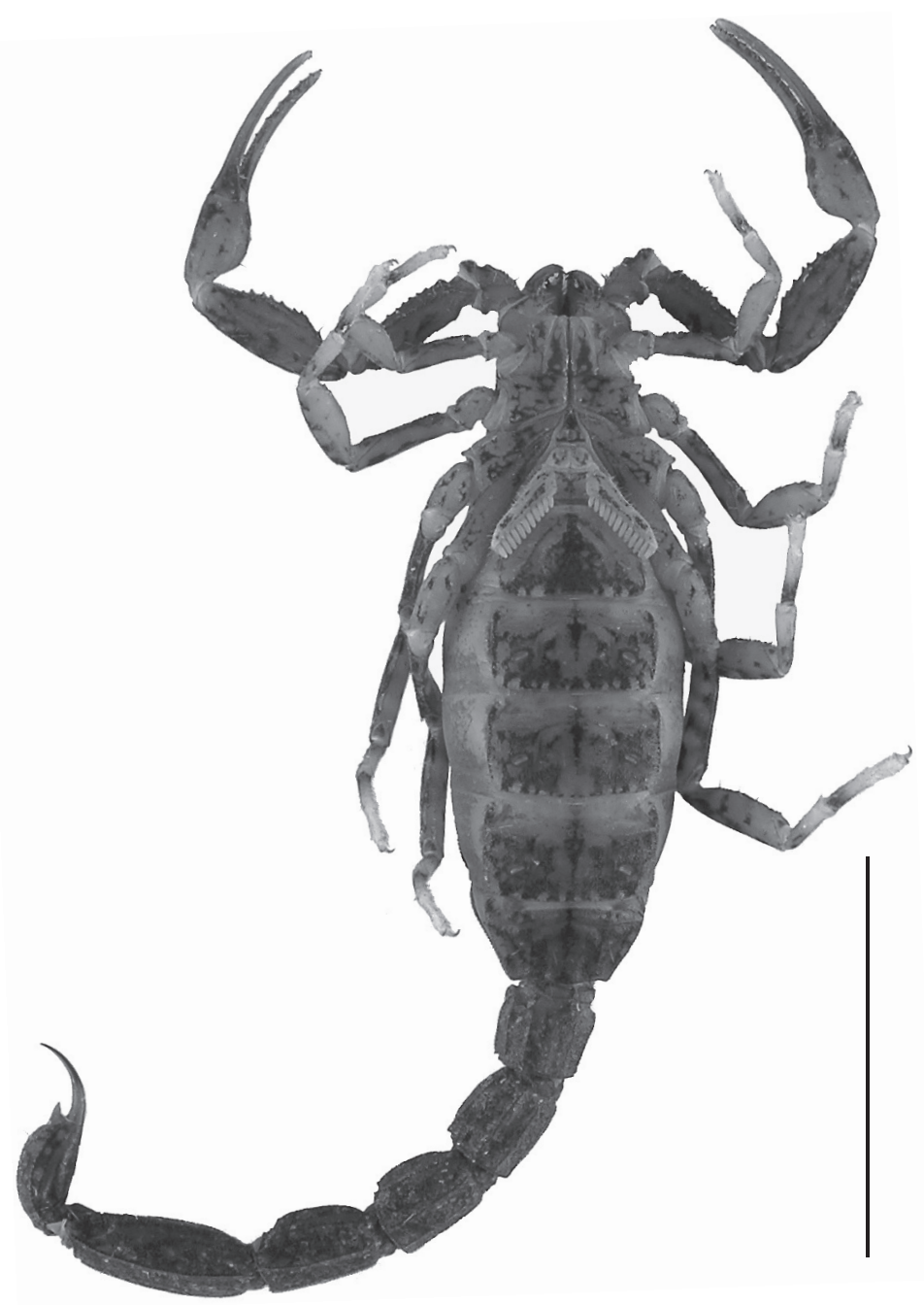

FIG. 3. - Lychas santoensis n. sp., holotype, habitus, ventral aspect. Scale bar: $1 \mathrm{~cm}$.

subaculear tooth, between rhomboid and spinoid; and 3) fulcra absent or inconspicuous (see also taxonomic remarks after the description).

\section{DESCRIPTION BASED ON FEMALE HOLOTYPE}

\section{AND PARATYPE}

\section{Colouration}

Generally reddish-yellow to reddish-brown with intense blackish variegated pigmentation. Prosoma: reddish-yellow, globally covered with blackish pigmented zones; eyes surrounded by black pigment. Mesosoma: tergites reddish-yellow with several blackish spots forming approximately three longitudinal strips. Venter yellowish, with dense variegated dark spots covering coxapophysis, sternum, genital operculum pectines and all sternites. Metasoma: segments reddish-yellow to reddish-brown intensely marked with blackish variegated spots. Ventral aspect of segments IV and V almost blackish. Vesicle reddish-yellow with intensely marked blackish spots; aculeus yellow at the base and reddish at its extremity. Chelicerae yellowish, intensely marked with blackish variegated spots which cover its entire surface; teeth reddish. Pedipalps: yellowish to reddish-yellow; 


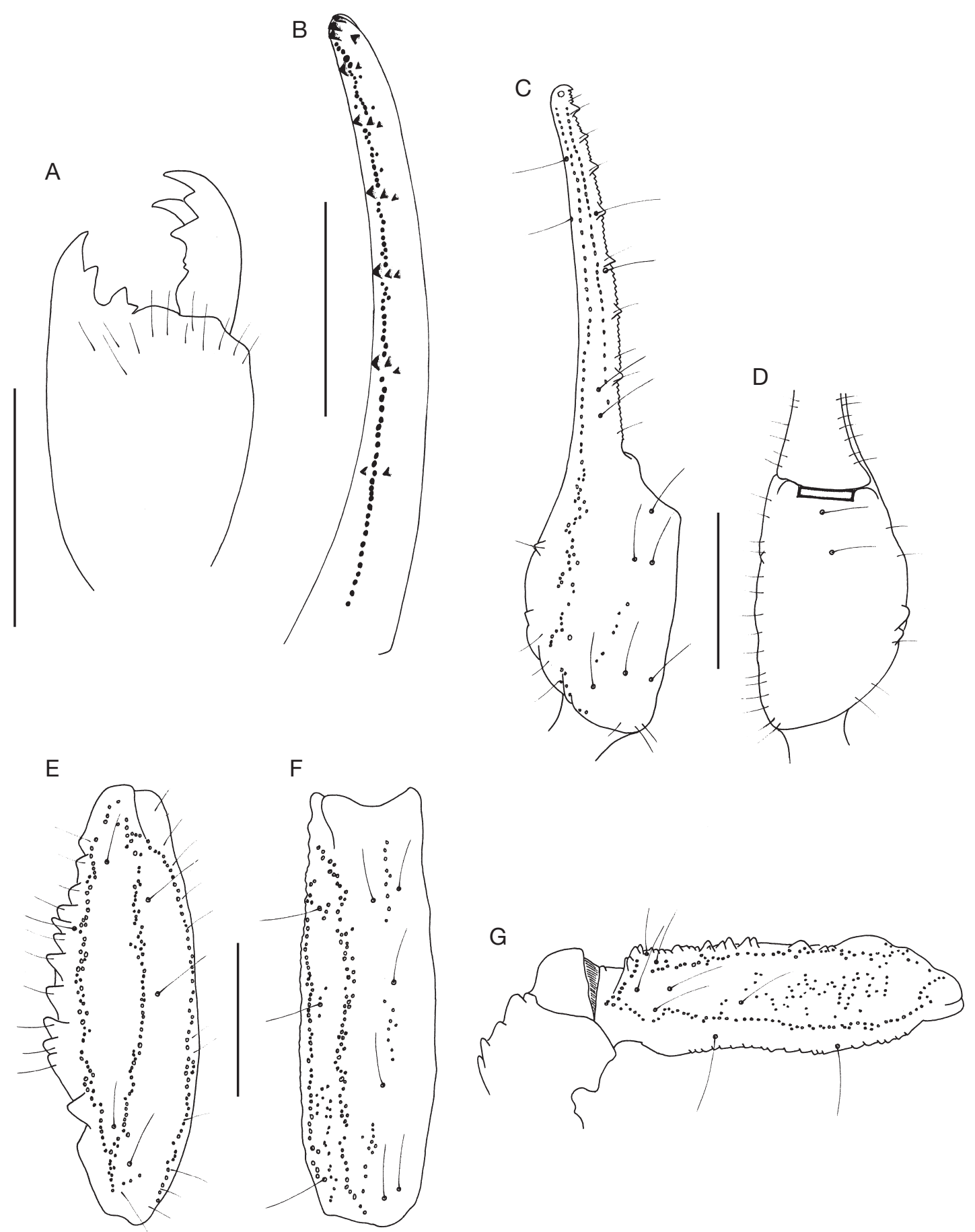

FIG. 4. - Lychas santoensis n. sp., o holotype: A, chelicera, dorsal aspect; B, dentate margin of movable finger, showing rows of granules; C-G, trichobothrial pattern; C, D, chela, dorso-external and ventral aspects; E, F, patella, dorsal and external aspects; G, femur, dorsal aspect. Scale bars: $1.5 \mathrm{~mm}$. 


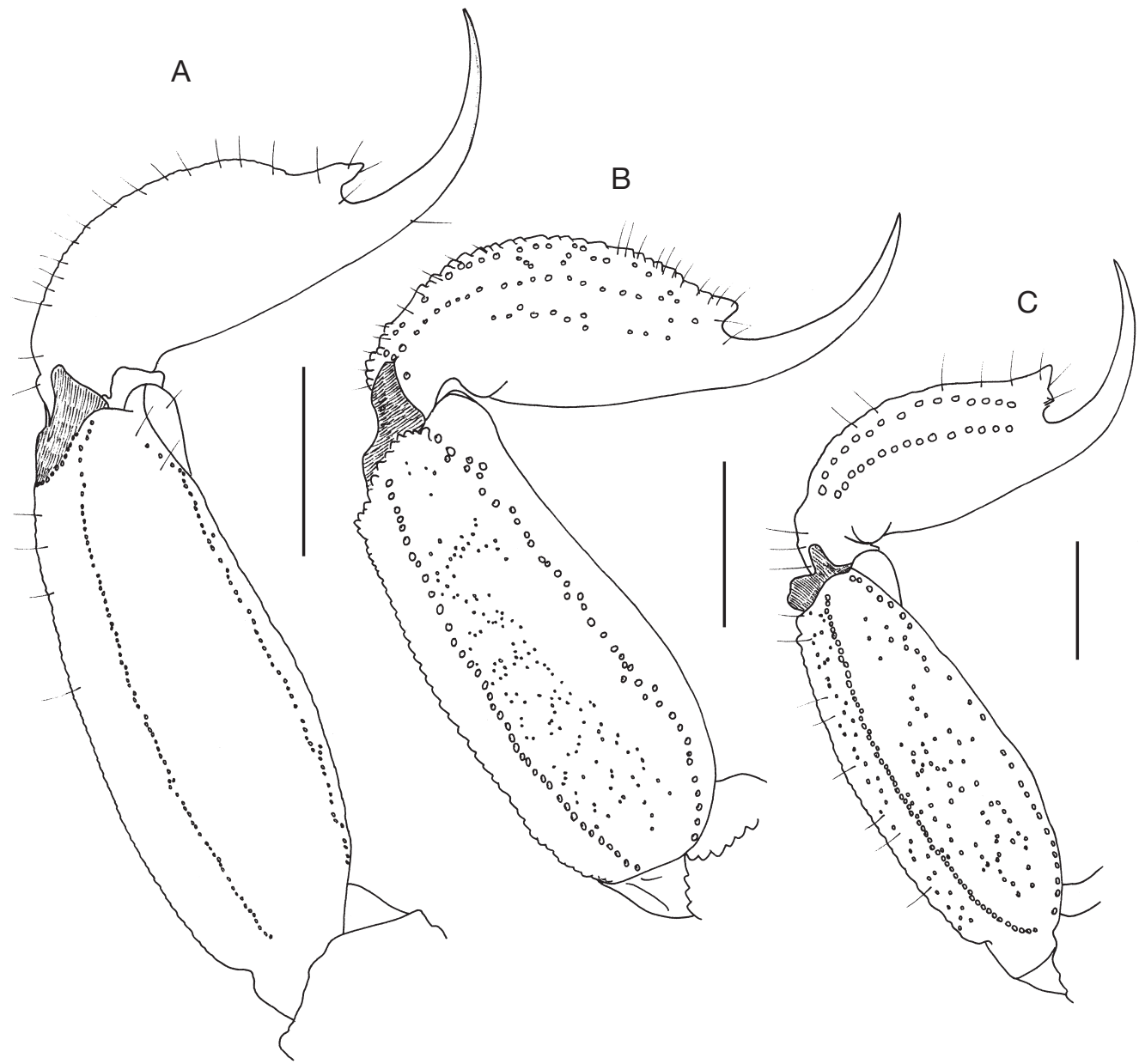

FIG. 5. - Metasomal segment V and telson, lateral aspect: A, Lychas santoensis n. sp., o holotype; B, L. perfidus (Keyserling, 1885), o paralectotype; C, L. variatus papuanus (Thorell, 1888), $ᄋ$ lectotype. Scale bars: $1.5 \mathrm{~mm}$.

femur and patella intensely marked with variegated blackish spots; chela yellowish with some blackish spots, much less marked than those of femur and patella; rows of granules on dentate margins of the fingers reddish. Legs yellowish intensely marked with blackish variegated spots.

\section{Morphology}

Prosoma: anterior margin of carapace moderately to strongly emarginate. Carapace carinae moderate to weak; anterior median and posterior median carinae moderately developed; other carinae weak to obsolete. Intercarinal spaces moderately granular. Median ocular tubercle anterior to the centre of the carapace; median eyes separated by one ocular diameter. Three pairs of lateral eyes. Mesosoma: tergites I-VI with a median carina; weak to obsolete on I, moderate on II-VI. Tergite VII pentacarinate, with lateral pairs of carinae moderate to strong; median carinae present in proximal half, moderately developed. Intercarinal spaces with a moderately to strongly marked granulation; similar to that of carapace. Sternites with moderately to weakly marked granulations; spiracles rather short; sternite VII more intensely granulated than other sternites and with four carinae. Pectines moderately long to small; pectinal teeth count 12 or 11 in holotype 
TABLE 1. - Morphometric values (in mm): male holotype and female paratype of Lychas variatus canopensis Lourenço \& Qi, 2007; female lectotype of $L$. variatus papuanus (Thorell, 1888); female lectotype of $L$. perfidus (Keyserling, 1885) and female holotype of L. santoensis n. sp.

\begin{tabular}{|c|c|c|c|c|c|}
\hline & \multicolumn{2}{|c|}{ L. variatus canopensis } & \multirow{2}{*}{$\begin{array}{c}\begin{array}{l}\text { L. variatus } \\
\text { papuanus }\end{array} \\
\text { Lectotype }\end{array}$} & \multirow{2}{*}{$\begin{array}{l}\text { L. perfidus } \\
\text { Lectotype }\end{array}$} & \multirow{2}{*}{$\begin{array}{l}\text { L. santoensis } \\
\text { n. sp. } \\
\text { Holotype }\end{array}$} \\
\hline & Holotype & Paratype & & & \\
\hline Total length & 27.3 & 28.6 & 44.0 & 33.9 & 31.0 \\
\hline \multicolumn{6}{|l|}{ Carapace: } \\
\hline length & 3.9 & 4.1 & 5.2 & 4.3 & 4.1 \\
\hline anterior width & 2.8 & 3.2 & 3.8 & 3.2 & 2.9 \\
\hline posterior width & 3.6 & 4.5 & 5.5 & 4.7 & 4.3 \\
\hline \multicolumn{6}{|c|}{ Metasomal segment I: } \\
\hline length & 2.1 & 2.6 & 2.8 & 2.3 & 2.0 \\
\hline width & 2.2 & 2.5 & 3.0 & 2.7 & 2.5 \\
\hline \multicolumn{6}{|c|}{ Metasomal segment V: } \\
\hline length & 4.7 & 5.2 & 6.2 & 5.2 & 4.9 \\
\hline width & 1.7 & 2.1 & 2.5 & 2.2 & 1.9 \\
\hline depth & 1.7 & 2.1 & 2.4 & 2.1 & 1.9 \\
\hline \multicolumn{6}{|l|}{ Vesicle: } \\
\hline width & 1.2 & 1.4 & 2.0 & 1.8 & 1.4 \\
\hline depth & 1.4 & 1.5 & 1.9 & 1.8 & 1.5 \\
\hline \multicolumn{6}{|l|}{ Pedipalp: } \\
\hline Femur length & 3.8 & 4.3 & 4.8 & 4.0 & 3.8 \\
\hline Femur width & 1.1 & 1.2 & 1.4 & 1.2 & 1.1 \\
\hline Patella length & 4.3 & 5.1 & 5.6 & 4.5 & 4.3 \\
\hline Patella width & 1.4 & 1.6 & 2.1 & 1.6 & 1.5 \\
\hline Chela length & 6.1 & 6.9 & 8.4 & 6.7 & 6.8 \\
\hline Chela width & 1.0 & 1.1 & 1.7 & 1.3 & 1.3 \\
\hline Chela depth & 1.0 & 1.1 & 1.6 & 1.3 & 1.3 \\
\hline \multicolumn{6}{|l|}{ Movable finger: } \\
\hline length & 4.2 & 4.9 & 5.9 & 4.8 & 4.5 \\
\hline
\end{tabular}

and 10 or 11 for paratype; fulcra absent or totally inconspicuous. Metasoma: segments I and II with 10 carinae, crenulate; III and IV with eight carinae, crenulate. Segment V with five carinae; absence of any posterior spinoid granule on the dorsal carinae of segments I-IV. Dorsal furrows of all segments weakly developed and with some thin granulations; intercarinal spaces moderately granular. Telson moderately elongated and weakly granular, with one ventral and two lateral carinae; aculeus moderately curved; subaculear tubercle moderate and between rhomboid and spinoid in shape; ventral granules inconspicuous. Chelicerae with the dentition characteristic of the buthids (Vachon 1963); two small but well distinct basal teeth on movable finger. Pedipalps: Femur pentacarinate; all carinae moderately crenulate. Patella with seven carinae, moderately crenulate; dorsointernal carinae with 6 or 7 spinoid granules. Chela with vestigial dorso-external carinae weakly crenulated, and no internal granules. Intercarinal spaces weakly granular on femur and patella; almost smooth on chela. Dentate margins on movable and fixed fingers composed of 6-7 (6) linear rows of granules; one very inconspicuous external accessory granule next to the most basal row of granules. Trichobothrial pattern type A, orthobothriotaxic (Vachon 1974); dorsal trichobothria of femur in $\beta$ (beta) configuration (Vachon 1975). Legs: ventral aspect of tarsi with a brush-like group of setae. Tibial spurs present on legs III-IV, moderately to strongly developed; pedal spurs present on all legs; reduced on legs I and II.

\section{Morphometric measurements}

See Table 1.

\section{TAXONOMIC REMARKS}

1) In the very precise diagnosis proposed by Vachon (1986) for the genus Lychas, the absence of fulcra 
is assumed to be observed only in very rare cases (Vachon 1986: 845, statement number 8: "fulcres externes présents, ces derniers rarement absents"). In the subsequent, but very superficial diagnosis proposed by Kovařik (1997), fulcra are indicated as always present. This assumption by Kovarik (1997) seems, however, to be based on a previous statement by Sissom (1990). The absence of fulcra in Lychas santoensis $\mathrm{n}$. sp. seems to bring further evidence to the observations done by Vachon (1986).

2) According to Vachon (1986), the dentate margins of movable finger of pedipalp bear a fundamental number of 6 linear rows of granules. In fact, the most distal row of granules is not included in the count. Since this distal row can be, in many cases, rather conspicuous, the actual number of counted rows of granules should be 7 instead of 6 .

\section{Acknowledgements}

The SANTO 2006 Expedition was organized by Muséum national d'Histoire naturelle, Paris, ProNatura International (PNI), and Institut de Recherche pour le Développement (IRD). It operated under a permit granted to Prof. P. Bouchet (MNHN) by the Environment Unit of the Government of Vanuatu. Within the expedition, terrestrial arthropods were collected as part of the the "Forests, Mountains, Rivers" theme coordinated by Dr B. Corbara, Prof. P. Keith and Dr J. Munzinger. Dr C. Rollard coordinated the collecting of the material studied in the present paper. The author wishes also to acknowledge Prof. John L. Cloudsley-Thompson, London and Dr Victor Fet (Marshall University, Huntington, USA) for most useful comments to the manuscript. Drs Janet Beccaloni (BMNH) and Giuliano Doria (MCSN) for the loan of the type material used in this study. Élise-Anne Leguin (MNHN), for the preparation of the photos used in the illustration of this publication.

\section{REFERENCES}

Bouchet P., Le Guyader H. \& Pascal O. 2008. — Des voyages de Cookà l'expédition Santo 2006: un renouveau des explorations naturalistes des îles du Pacifique. Journal de la Société des Océanistes, 126-127: 167-185.
Bouchet P., Le Guyader H. \& Pascal O. (eds) in press. - The Natural History of Santo. Patrimoines Naturels.

Francke O. F. \& Lourenço W. R. 1991. — Scorpions (Arachnida) from Rennell Island, in WolfF T. (ed.), The Natural History of Rennell Island, British Solomon Islands. The University of Copenhagen, Copenhagen, 8: 199-204.

HJELlE J. T. 1990. - Anatomy and morphology, in Polis G. A. (ed.), The Biology of Scorpions. Stanford University Press, Stanford: 9-63.

КосH L. E. 1977. — The taxonomy, geographic distribution and evolutionary radiation of Australo-Papuan scorpions. Records of the Western Australian Museum 5 (2): 83-367.

KOVAŘIK F. 1997. - Revision of the genera Lychas and Hemilychas, with descriptions of six new species (Scorpiones: Buthidae). Acta Societatis Zoologicae Bohemoslovenicae 61: 311-371.

LOURENÇO W. R. 1985. - Essai d'interprétation de la distribution du genre Opisthacanthus (Arachnida, Scorpiones, Ischnuridae) dans les régions néotropicale et afrotropicale. Étude taxinomique, biogéographique, évolutive et écologique. Thèse de Doctorat d'État, Université Pierre et Marie Curie, Paris, France, 287 p.

LOURENÇO W. R. 2008. — Parthenogenesis in scorpions: Some history - new data. Journal of Venomous Animals and Toxins including Tropical Diseases 14 (1): 19-44.

LOURENÇO W. R. \& Q Q J. X. 2007. — Scorpions from the rainforest canopy of New Guinea and description of a new subspecies of Lychas C. L. Koch, 1845 (Scorpiones: Buthidae). Bulletin de l'Institut royal des Sciences naturelles de Belgique, Entomologie 77: 157-161.

MONOD L. 2000. — Révision systématique du genre Liocheles (Scorpiones, Ischnuridae). Mémoire de DEA, Université de Genève, Suisse, 143 p.

Sissom W. D. 1990. - Systematics, biogeography and paleontology, in Polis G. A. (ed.), The Biology of Scorpions. Stanford University Press, Stanford: 64-160.

STAHnKe H. L. 1970. - Scorpion nomenclature and mensuration. Entomological News 81: 297-316.

VACHON M. 1952. - Études sur les scorpions. Publications de l'Institut Pasteur d'Algérie, Alger, 482 p.

VACHON M. 1963. - De l'utilité, en systématique, d'une nomenclature des dents des chélicères chez les Scorpions. Bulletin du Muséum national d'Histoire naturelle, Paris, 2e sér., 35 (2): 161-166.

VACHON M. 1974. — Étude des caractères utilisés pour classer les familles et les genres de Scorpions (Arachnides). 1. La trichobothriotaxie en arachnologie. Sigles trichobothriaux et types de trichobothriotaxie chez les Scorpions. Bulletin du Muséum national d'Histoire naturelle, Paris, 3e sér., n 140 , Zoologie 104: 857-958 (dated 1973, published 1974). 
VACHON M. 1975. — Sur l'utilisation de la trichobothriotaxie du bras des pédipalpes des Scorpions (Arachnides) dans le classement des genres de la famille des Buthidae Simon. Comptes Rendus de l'Académie des Sciences, Paris, sér. D, 281: 1597-1599.
VACHON M. 1986. — Étude de la denture des doigts des pédipalpes chez les Scorpions du genre Lychas C. L. Koch, 1845 (Arachnida, Scorpiones, Buthidae). Bulletin du Muséum national d'Histoire naturelle, Paris, 4e sér., sect. A, 8 (4): 835-850.

Submitted on 3 March 2009; accepted on 3 July 2009. 